Legal Sciences

UDC 347.633

Kovalova Daria

PhD Student of the

Dokuz Eylül University

ORCID: 0000-0003-2711-0149

\title{
REQUIREMENTS APPLICABLE TO THE ADOPTIVE CANDIDATES ACCORDING TO THE LEGISLATION OF UKRAINE AND THE REPUBLIC OF TURKEY
}

Summary. The objective of the article is to analyze the requirements, that were put forward to the adoptive candidates according to the legislation of Ukraine and the Republic of Turkey. Particularly, were analyzed the norms of the Family Code of Ukraine and the Civil Code of the Republic of Turkey, points of view of Ukrainian and Turkish scientists regarding the requirements for adopting candidates.

Key words: adoption; adoptive parent; requirements; the Family Code of Ukraine; the Civil Code of the Republic of Turkey.

It is well known that the problem of an orphanhood has existed since ancient times and today it has not been able to bypass any country in the world. In all corners of our planet, every child wants to live and be raised in a family. It should be emphasized that this is not only child's wish, but also the right enshrined in the Convention on the Rights of the Child (hereinafter - the Convention) [1], which was ratified by Ukraine on 27 February 1991 and by the Republic of Turkey (hereinafter - Turkey) on 14 October 1990. In Preamble of the Convention is determined that, the child, for the full and harmonious development of his or her personality, should grow up in a family environment, in an atmosphere of 
happiness, love and understanding. But, it often happens that the child does not have the opportunity to grow up surrounded by biological parents. For children who for one reason or another have been left without parental care, a form of family upbringing is provided, as a result of which the child leaves the system of state guardianship and custody, losing the status of an orphan or a child left without parental care - adoption. In order for the child's life in the adopted family to be as comfortable as possible and for the child to really feel "at home", the legislators put forward a number of requirements for adoptive parents.

The main document of Turkey, which contains the requirements for adopters - is the Civil Code of Turkey (hereinafter - the CCT) [2], in Ukraine - is the Family Code of Ukraine (hereinafter - the FCU) [3].

According to Art. 3 of the Convention, in all actions concerning children, whether undertaken by public or private social welfare institutions, courts of law, administrative authorities or legislative bodies, the best interests of the child shall be a primary consideration. İn turn according to Art. 305/II of the CCT, adoption must be in the best interests of the child, and the adopter's other children's interests should not be unduly injured.

According to Turgut Akintürk, the fact that adoption should be in the best interests of the child is the most important condition for adoption. Even if all other conditions are met, except this one, the decision on adoption will not be made [4, p. 294]. It is obvious that this condition of adoption is at the same time a requirement for the adopter. That is, under this condition, the legislator requires the adopter, first of all, to be able to create such conditions for life and comprehensive development of the child that will meet his/her best interests, if the adopter is unable to do so, the adoption will not take place, even if the adopter meets all other requirements specified in the CCT. According to Art. 207/II of the FCU, adoption of a child is effected in the best interests of the child to ensure $\mathrm{him} /$ her a stable and harmonious life conditions. 
Based on the above, it becomes clear that in both countries the legislator puts the interests of the child on the first place and adoption is carried out only if it really meets child's best interests.

The next thing to pay attention to is the age of adopters. According to Art. 211/I of the FCU, a legally capable person that is at least 21 years old may be an adopter.

According to Art. 306 of the CCT, spouse applicants shall be married for at least five years or both of them should be at least thirty years old. If the child of one of the spouses is adopted by the other (stepmother or stepfather), they must be married for at least two years or the age of the stepmother/stepfather must be not less than thirty years. According to Art. 307 of the CCT, if applicant is an unmarried person, his/her age has to be not less than thirty years old.

Accordıng to Murat Aydoğdu's point of view, the legislator chose age thirty years because people who have reached this age (especially women) in terms of maturity and knowledge can more take care of the child and there will be no immoral wrong thoughts in the actions of adults who think maturely [5, p. 307].

The age difference between a child and an adoptive parent, according to Art. 211/II of the FCU, must be at least fifteen years. In the case of the adoption of an adult, the age difference may not be less than eighteen years. In Turkey, an adoptive parent may be a person who is at least eighteen years older than the child he/she wishes to adopt. Regarding the age difference in the adoption of an adult or an adult with a disability, it is also 18 years (there is no apart provision in CCT for this regulation, so it's regulated by analogy). There are also other requirements to adoptive parents who want to adopt an adult or an adult with a disability. First of all, in order to adopt an adult or a person with a disability, the adopter must obtain the consent of his descendants. Second, adopting a person with a disability, the adopter had to take care of him/her for at least five years. Third, the adopter had to take care of an adult or a person with a disability at least five years during his/her childhood. Finally, if there are other significant circumstances and the 
adopter and the adoptee have lived together in the same family for at least five years, the adoption can be carried out.

With the adoption of adults, in Ukraine the legislator does not make such demands on adoptive parents, but the court takes into account the marital status of the adoptive parent, in particular the absence of children and other significant circumstance [6, p. 73]. It's well known, the list of such circumstances is not exhaustive. The court practice shows that there are cases where courts give permission for adoption to people who have their own children, taking into account the applicant's financial situation and his plans to divide the inheritance among all his children.

There is no age limit after which a person cannot become an adoptive parent and the maximum age difference between a child and an adoptive parent in the current legislation of Ukraine and Turkey.

It is well known that the family upbringing meets the best interests of the child, so the adoptive parents can be, above all, spouses. According to the family law of Ukraine, persons who are not married to each other cannot adopt the same child. But if they live as a family, the court may decide to adopt the child. Thus, persons living in a civil marriage can adopt the same child, but they have to prove that they live together as a real family. Accordıng to Turkish family legislation, persons who are not married to each other cannot adopt the same child.

In addition, a couple should be understood as a man and a woman, adoptive parents cannot be of the same sex. First, both same-sex marriages are prohibited in both Ukraine and Turkey, and second, it is completely contrary to nature.

The following requirement for adoptive parents in Turkey may seem unusual from the point of view of Ukrainian family law. Applicants should care and educate the child at least for one year before adoption ruling. The most interesting thing is that they should do it not only in free time or on weekends, but they should live with the child. In the scientific literature, it is noted that the legislator determines this time as a time for experience and reflection, a time 
during which it is possible to understand whether such adoption will meet the best interests of the child [7, p. 570].

Analyzing the above, it can be argued that the requirements for adopters in Ukraine and Turkey have their similarities and differences, which are due to the culture, history and political characteristics of each of these countries. Legislators of Ukraine and Turkey make high demands on adopters, taking into account the peculiarities of national legislation. The requirements put forward guarantee the ensuring respect for the rights of the adopted child and are aimed at ensuring that, as a result of adoption, the child will be in a family where not only favorable conditions for its comprehensive and full development will be created, but also conditions in which the child will be able to feel the warmth of the family hearth.

\section{References}

1. Конвенція ООН про права дитини // Верховна Рада України. URL: https://zakon.rada.gov.ua/laws/show/995_021

2. Türk Medeni Kanunu // T.C. Cumhurbaşkanlığı Mevzuat Bilgi Sistemi. URL: https://www.mevzuat.gov.tr/MevzuatMetin/1.5.4721.pdf

3. Сімейний кодекс України // Верховна Рада України. URL: https://zakon.rada.gov.ua/laws/show/2947-14

4. Akıntürk Turgut, Ateş Karaman Derya. Medeni Hukuk. İstanbul, 2013. 583 S.

5. Aydoğdu Murat. Çağdaş Hukuki Gelişmeler Işığında Evlat Edinme. 2. Bask1. Ankara, 2010. $811 \mathrm{~s}$.

6. Труба В. I. Усиновлення повнолітніх: питання законодавства i практики / В. І. Труба // Правова держава. - 2014. - № 17. - С. 72-75.

7. Öztan Bilge. Aile Hukuku. 5. Bask1, Ankara, 2004. 784 s. 